\title{
Outcomes of Homework on Facebook: A Case Study from an English for Academic Purposes Course
}

\author{
Juraj Datko
}

\begin{abstract}
The paper aims to find out the outcomes of homework and bonus activities on Facebook through three categories, namely "participation", "preference", and "convenience". University students $(N=34)$ participated in this research which was conducted in the "English for Academic Purposes 1" course taught by the author. The case study uses statistical data from our Facebook study group and qualitative data from student diaries. The results indicate a moderate-to-high students' participation in Facebook assignments and that participation in these activities is influenced by reward, effort, study environment, and workload from other subjects. The findings also show that students prefer collaborative tasks. Furthermore, Facebook homework is viewed as more convenient than traditional paper-based homework due to time-space independence, familiarity of the platform, and the ability to save time.
\end{abstract}

Index Terms-Blended learning, case study, English for academic purposes, Facebook group, foreign language pedagogy.

\section{INTRODUCTION}

Multimodal instruction that blends contact classes with an electronic, out-of-class component is widely used in tertiary education. These components (i.e. learning management systems) are valuable tools that help teachers organize the content and the process of learning; they are also digital storages and platforms for various activities and forms of interaction, feedback, and evaluation.

In our teaching experience, however, we often face students' complaints about these tools. They are usually related to their structural rigidity, non-appealing graphics, unfriendly user interface, or instability.

These challenges made us think about employing an alternative online learning environment - an e-platform that is integrated in digital natives' lives and similar in functionality.

To use a Facebook group as a substitute for a traditional Moodle course was a choice based on three principles:

1) Integration - Facebook is the largest social networking site with around 2.7 billion monthly active users [1], and it is accessed at least once during classes by almost $50 \%$ of the students [2];

2) E-learning 2.0 - Facebook groups fit the definition of

Manuscript received November 11, 2020; revised February 19, 2021. This work was supported by "Univerzitná Grantová Agentúra", Grant "V/6/2020 Technické a kolaboratívne aspekty facebookovej skupiny ako alternatívy k LMS" and "Agentúra na podporu výskumu a vývoja", Grant “APVV-15-0368 Prax v centre odborovej didaktiky, odborová didaktika v Centre praktickej prípravy".

Juraj Datko is with the Department of Language Pedagogy and Intercultural Studies at Constantine the Philosopher University in Nitra, Slovakia (e-mail: jdatko@ukf.sk). "social software", the umbrella term used for "networked tools that support and encourage individuals to learn together while retaining individual control over time, space, presence, activity, identity and relationship" [3];

3) Exploration - Since a Facebook group is a dynamic environment, it "challenges the learners [...] to provide original and creative solutions for learning" [4], and we wanted to explore these.

The above principles provide a solid ground for using a Facebook group as a pedagogical tool in the education process. But the principal question that is addressed in this paper is that whether it could be a useful platform for homework from English.

\section{LITERATURE REVIEW}

\section{A. Outcomes of Educational Facebook Use}

In the last decade, many authors have contributed to the body of literature on Facebook use in education. In fact, it was the most studied learning and teaching environment [5].

We discuss its impact in higher education from a multitude of perspectives, including motivation, student engagement, autonomous learning, social and collaborative learning, communication, socialization, and academic achievement.

The outcomes of previous research are often mixed. The findings are divided when it comes to the influence of Facebook on students' motivation to learn English as a foreign language (EFL). On the one hand it was indicated that hybrid instruction based on contact classes and Facebook groups can have a positive impact on students' motivation to learn English [6] and on their attitude towards this activity [7], but on the other hand research also showed that students' motivation to learn English either was not visibly affected [8] or vanished after the novelty abated [9].

The motivational effect of Facebook use can be seen in students' involvement in EFL writing activities. Their active engagement in writing was promoted by interactivity of the platform [10] and group audience [11], [12].

Furthermore, the sense of being exposed to the audience of a Facebook group can contribute to self-regulated EFL learning. Students tend to be more cautious about their writing style or grammar if they expect that their writing output can be accessed by the teacher or more proficient classmates [9], [13]. Taking such responsibility for one's own foreign language outcome adds to autonomy [12].

It is not only the group audience that triggers active learning, but also the Facebook group's dynamic and non-hierarchical structure, although this was seen by students as inconvenient [4]. 
What is not perceived as problematic is communication with other group members. On the contrary, students signified peer communication that happened beyond the confines of the classroom as one of the major assets of using Facebook groups in formal education [14]-[16].

In the case of EFL pedagogy, extended student-student and student-teacher communication (such as group discussions on classwork and study problems, sharing ideas, or giving / receiving feedback) means extended exposure to the English language, which can improve students' writing skills [10], [17].

Communication goes hand in hand with social constructivist learning which is based on conversation and collaboration [18]-[20]. Facebook groups promote both direct collaboration (through interaction and creation / sharing of resources and practices) and indirect collaboration (through peer observation) [21], and thus contribute to better learning [22].

Educational use of Facebook does not only improve an individual but also their social bond with others. Particularly, it helped in building community and socialization [23]-[26].

Last but not least is the impact of Facebook use on academic performance. This aspect gained recognition also in mainstream media after a negative correlation between Facebook use and grades was found [27]-[30]. Some authors, however, rejected the hypothesis, since their data pointed to a positive correlation [31], [32] or no correlation at all [33], [34].

Later, the findings that rendered empirical research on the connection between the intensity of Facebook usage and variables of academic achievement were systematized in a meta-analysis with the following outcomes: the more school-related presence on Facebook, the better the academic achievement; Facebook presence unrelated to school during school-related activities is associated with lower academic achievement; and intensive presence on Facebook (in terms of the overall time spent) lowers academic achievement [35].

\section{B. Outcomes of Homework on Facebook}

Research on Facebook groups as homework platforms is similarly divided, at least when it comes to students' preferences, attitudes, or learning outcomes.

The reported preferences reflect a shift towards "e-homework" and social constructivist learning. Students favored Facebook homework over paper-based homework (which was illustrated by questionnaire data and a relatively high mean participation - 9.5 from a possible 11 ) and agreed that ease of use, convenience, media richness, collaboration, and social bond are its main benefits [36], [37].

Ease of use was seen as the major one. Most students accessed Facebook homework via portable devices (smartphones and tablets) and found making posts easy [36], [37]. This contributed to the perceived usefulness of Facebook groups which in turn positively influenced language learning performance [37].

However, it seems that some students are not fully prepared to step out of their comfort zone. They preferred teacher-directed Facebook activities and often lacked confidence to share their output in the Facebook group, although they wanted to be part of the learning community
[38].

Anxiety is not the only reported inhibitor in learning activities on Facebook. Though doing activities in Facebook groups was generally described as convenient, motivating, or time-saving [37], students sometimes had difficulties with following the posts in their groups due to a busy schedule [9], a preference for traditional reading [10], and imminent assignments / exams [12].

The last aspect that is discussed is language learning potential. It was concluded that Facebook assignments improve students' writing skills in terms of grammar, vocabulary, spelling, punctuation, and paragraph organization [37], [39]-[41]. However, Facebook use can encourage deviant forms in writing such as informal short forms or simplified syntax [42].

\section{Methodology}

\section{A. Research Aim}

The aim of this paper is to find out the outcomes of homework and extra tasks on Facebook through three categories, namely "participation", "preference", and "convenience".

\section{B. Participants}

Undergraduates from a mid-sized, public university $(N=34)$ participated in the present case study. The research sample consisted of pre-service teachers $\left(N^{1}=22\right)$ and future health \& safety managers $\left(N^{2}=12\right)$. Participants were labelled "a" (cohort 1 - summer 2018/2019; $N^{a}=15$ ) and "b" (cohort 2 winter 2019/2020; $N^{b}=19$ ). They attended the "English for Academic Purposes" (EAP) optional course taught by the author and joined its accompanying Facebook group. In order to assure a high level of privacy, the mentioned Facebook group was secret. All students gave consent for their information to be used for research purposes. Ethical approval was granted by the university.

\section{Facebook Assignments}

In each semester, the participants were told that they can benefit in the overall assessment by completing voluntary homework assignments and extra tasks. Homework was posted in the Facebook group after contact classes and included the following five tasks: 1.) Creating a picture dictionary, 2.) Creating a database of facts about schooling, 3.) Analyzing the structure of an abstract, 4.) Writing a motivation letter, and 5.) Answering tricky job interview questions. There were slight alternations among the five, spontaneous extra tasks which generally focused on answering questions, finding and correcting errors, and arranging sentences. All activities respected B2 level of English proficiency, which was the level reported by the students.

A successful completion of Facebook assignments required both lower-order and higher-order thinking skills. According to the revised Bloom's Taxonomy [43], the cognitive processes included understanding, applying, analyzing, and creating.

\section{Research Methods}




\section{1) Data collection}

Semi-standardized student diaries represented the first source of data. Students handed them in during weekly contact classes. They described further context of their interactions with the assignments, such as pinpointing the place where they had completed a task or naming other group members they had contacted in the process. They were also asked to express their attitudes towards the posted activities.

Screenshots of the group wall served as the second data source. Their major role was to validate students' diary entries on their involvement in the Facebook assignments. They also helped us determine the factors that had influenced students' participation and the preferred types of activities.

\section{2) Data analysis}

Since our case study was exploratory in nature, we opted for inductive coding in the process of diary analysis. First, we coded raw diary data (606 entries collected over a two-semester period) with preliminary categories, namely "general information", "favorability", and "experience". Second, these initial category labels were further refined as we proceeded with the process. This resulted in the creation of the final system of categories and codes that includes:

Participation - students' engagement in homework and extra tasks on Facebook;

Preference - students' inclination to collaborative or individual Facebook assignments;

Convenience - easy access, trouble-free usability, or time / space independence.

Statistical and content analysis of Facebook data not only objectified diary data on students' participation, what they believed was linked to it, or what they preferred, but it also played a crucial part in identifying effort as one of the contributing factors.

\section{FINDINGS}

\section{A. Participation}

All participants $(\mathrm{N}=34)$ produced data related to homework and extra tasks in the Facebook group. That they completed a Facebook assignment was noted 171x in the diaries. Although the diary records showed consistency with Facebook data, several interactions were missing. The next tables (Tables I, II, III, and IV) showing participation are therefore based on the data from the Facebook group.

\section{1) Cohort 1}

First, we look at students' participation in the "Facebook assignments" as a whole. Students from cohort 1 could participate in 10 language learning activities on Facebook in total. The highest score of participation was 9 , the lowest score was 6 , and the mean score was 7.7. When it comes to the results of individual participants, four students (4a, 6a, 13a, and 17a) participated in 9 activities, six students (3a, 5a, 10a, 14a, 16a, and 18a) in 8, two students (1a and 7a) in 7, and three students (2a, 12a, and 15a) submitted 6 assignments totally.

Second, we discuss students' participation in "homework" and "extra tasks" on Facebook separately. The highest possible (also achieved) score of participation in "homework" was 5, the lowest score was 3, and the mean score was 4.4. Students could also participate in 5 additional "extra tasks" in the Facebook group. The peak score of participation in the extras was 4 , the minimum score was 2 , and the mean score was 3.3. Students' results show that seven students (4a, 6a, 10a, 13a, 14a, 17a, and 18a) completed all homework assignments, another group of seven $(2 \mathrm{a}, 3 \mathrm{a}, 5 \mathrm{a}$, 7a, 12a, 15a, and 16a) completed 4, and one (1a) completed 3. It is also clear from the data that eight students (1a, 3a, 4a, 5a, 6a, 13a, 16a, and 17a) completed 4 extra activities, four students (7a, 10a, 14a, and 18a) completed 3, and three students (2a, 12a, and 15a) did 2 .

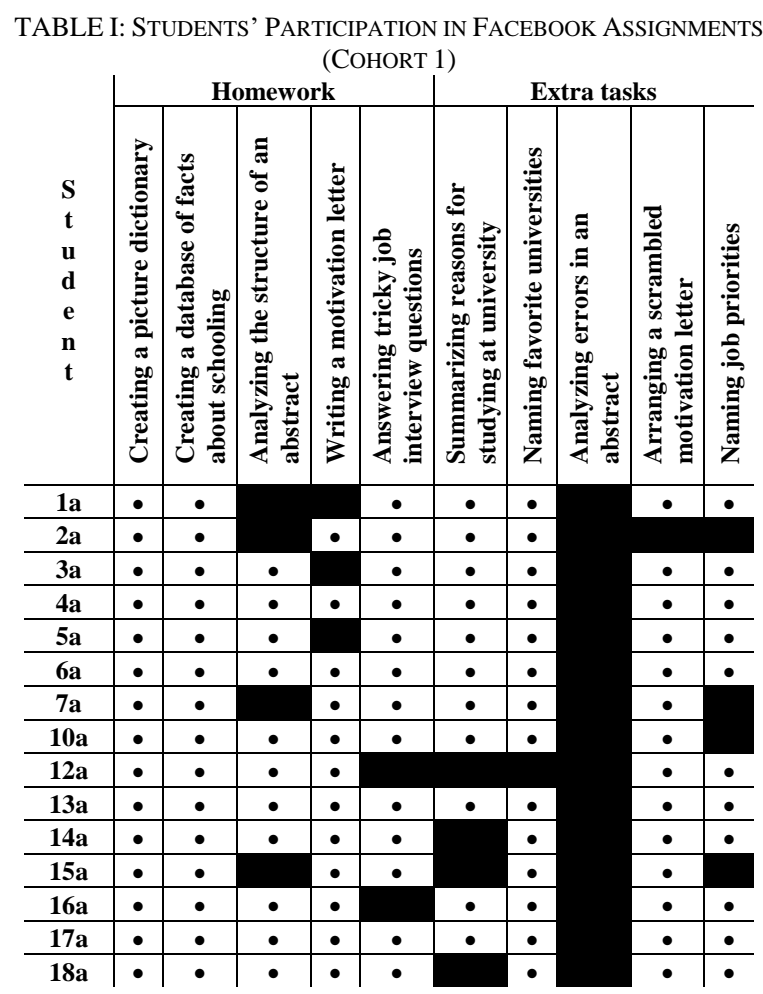

From the point of view of students' participation in individual homework assignments and extra tasks, the least successful homework was "Analyzing the structure of an abstract" with the mean score 0.7 (followed by "Writing a motivation letter" with 0.8 , and "Answering tricky job interview questions" with the mean at almost 0.9), and the least successful extra activity was "Analyzing errors in an abstract" with 0 participation (followed by "Summarizing reasons for studying at university" / "Naming job priorities" with the mean score 0.7 and "Naming favorite universities" / "Arranging a scrambled motivation letter" with 0.9 ).

\section{2) Cohort 2}

In cohort 2, the interval of students' engagement in all "Facebook assignments" was from 5 to 10, with the mean score of 7.5. Both the highest possible score and the lowest achieved score $(10 / 5)$ were distributed among two students (13b / 19b being the most active and $4 \mathrm{~b} / 15 \mathrm{~b}$ being the least active). Four students (5b, 9b, 11b, and 18b) participated in 9 assignments, two students ( $8 \mathrm{~b}$ and $17 \mathrm{~b}$ ) in 8 , seven students (1b, 2b, 6b, 7b, 10b, 12b, and 20b) in 7, and two students (14b and 16b) engaged in 6 activities.

Students' participation in "homework" was relatively high, 
as the score varied between 4 and 5 , with mean at 4.8 . Participation in the "extra tasks" ranged from 0 to 5 (which is the highest possible score). The mean score was 2.6. The score distribution was as follows: sixteen students (1b, 2b, 4b, $5 \mathrm{~b}, 6 \mathrm{~b}, 8 \mathrm{~b}, 9 \mathrm{~b}, 10 \mathrm{~b}, 11 \mathrm{~b}, 12 \mathrm{~b}, 13 \mathrm{~b}, 14 \mathrm{~b}, 17 \mathrm{~b}, 18 \mathrm{~b}, 19 \mathrm{~b}$, and 20b) did not miss any homework assignment (from 5 possible) and three students $(7 \mathrm{~b}, 15 \mathrm{~b}$, and $16 \mathrm{~b}$ ) submitted 4; two students (13b and 19b) participated in all 5 extra tasks, four students $(5 \mathrm{~b}, 9 \mathrm{~b}, 11 \mathrm{~b}$, and $18 \mathrm{~b})$ completed 4 , three students (7b, 8b, and 17b) did 3, seven students (1b, 2b, 6b, 10b, 12b, $16 \mathrm{~b}$, and 20b) participated in 2, two students ( $14 \mathrm{~b}$ and $15 \mathrm{~b}$ ) engaged in 1 , and one student ( $4 \mathrm{~b}$ ) did not respond to any of the extra tasks in the Facebook group.

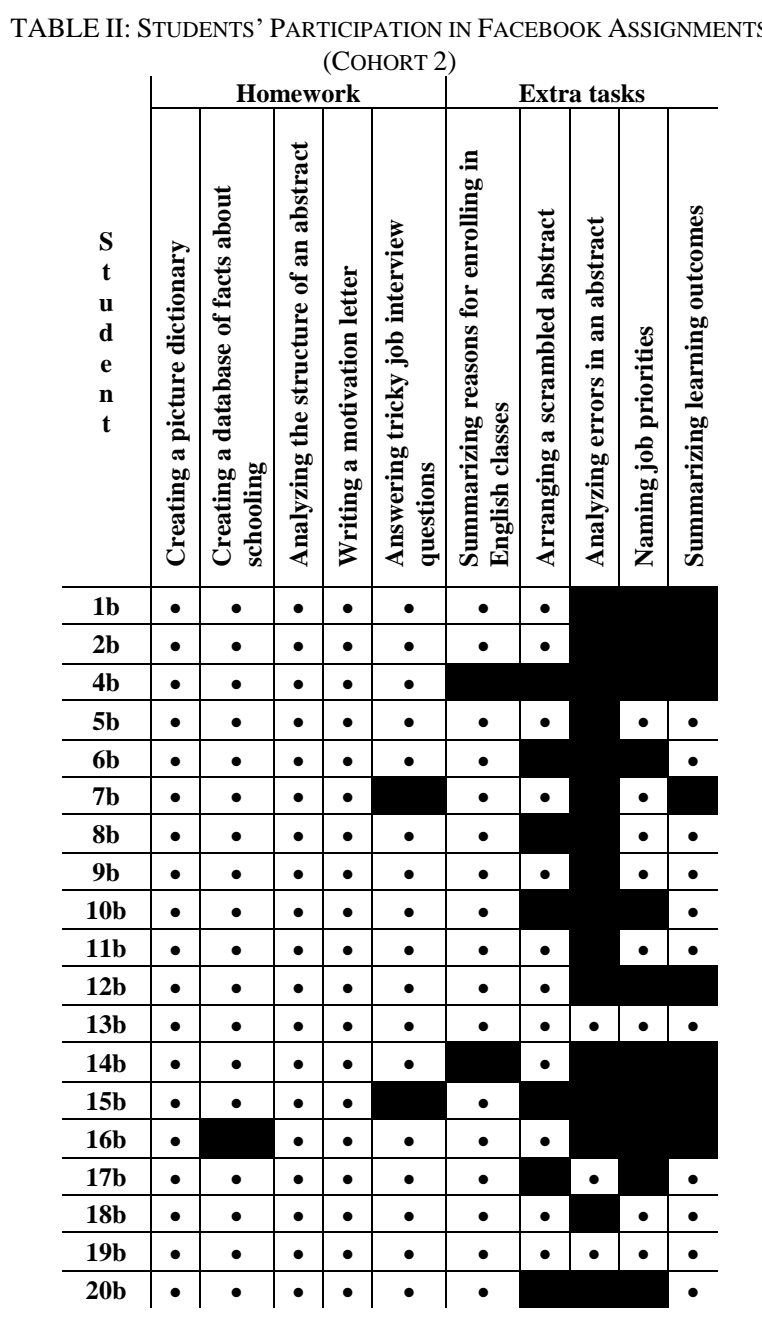

In terms of the students' engagement in individual activities, lowered participation occurred in two homework assignments, namely in "Answering tricky job interview questions" (the mean score almost 0.9) and "Creating a database of facts about schooling" (the mean score just over 0.9), and in all extra tasks. In most cases, a relatively low mean participation was calculated ("Analyzing errors in an abstract" - 0.1, "Naming job priorities" - 0.4, "Summarizing learning outcomes" - almost 0.6, and "Arranging a scrambled abstract" - just over 0.6). The extra task "Summarizing reasons for enrolling in English classes", achieved the mean score of almost 0.9.

\section{3) Cohorts $1 \& 2$}

The mean scores summarized above indicate comparable levels of overall participation and homework participation across the two cohorts. The mean scores in extra tasks show a higher activity in cohort 1.

\begin{tabular}{|c|c|c|c|}
\hline Cohort & \multicolumn{2}{|c|}{$\begin{array}{c}\text { Participation (max. total / max. achieved / min. } \\
\text { achieved / } \overline{\mathbf{x}})\end{array}$} & $\begin{array}{l}\text { K ASSIGNMENTS } \\
\text { ieved / min. }\end{array}$ \\
\hline Cohort & $\begin{array}{c}\text { All Facebook } \\
\text { assignments }\end{array}$ & $\begin{array}{c}\text { Facebook } \\
\text { homework }\end{array}$ & $\begin{array}{c}\text { Facebook extra } \\
\text { tasks }\end{array}$ \\
\hline $1\left(N^{a}=15\right)$ & $10 / 9 / 6 / 7.7$ & $5 / 5 / 3 / 4.4$ & $5 / 4 / 2 / 3.3$ \\
\hline $2\left(N^{b}=19\right)$ & $10 / 10 / 5 / 7.5$ & $5 / 5 / 4 / 4.8$ & $5 / 5 / 0 / 2.6$ \\
\hline
\end{tabular}

TABLE IV: MEAN SCORES OF STUDENTS' PARTICIPATION IN INDIVIDUAL

\begin{tabular}{|c|c|c|c|c|c|}
\hline \multirow[b]{2}{*}{ Homework } & \multicolumn{5}{|c|}{ FACEBOOK ASSIGNMENTS (COHORTS $1 \& 2$ ) } \\
\hline & $\begin{array}{c}\text { cohort } \\
1 \\
\end{array}$ & $\begin{array}{c}\text { cohort } \\
2\end{array}$ & Extra task & $\begin{array}{c}\text { cohort } \\
1 \\
\end{array}$ & $\begin{array}{c}\text { cohort } \\
2 \\
\end{array}$ \\
\hline $\begin{array}{c}\text { Creating a } \\
\text { picture } \\
\text { dictionary }\end{array}$ & 1 & 1 & $\begin{array}{c}\text { Summarizing } \\
\text { reasons for } \\
\text { studying at } \\
\text { university / } \\
\text { enrolling in } \\
\text { English } \\
\text { classes }\end{array}$ & 0.733 & 0.894 \\
\hline $\begin{array}{c}\text { Creating a } \\
\text { database of } \\
\text { facts about } \\
\text { schooling } \\
\end{array}$ & 1 & 0.947 & $\mathbf{X}$ & $\mathrm{X}$ & $\mathrm{X}$ \\
\hline $\begin{array}{l}\text { Analysing } \\
\text { structure of } \\
\text { an abstract }\end{array}$ & 0.733 & 1 & $\begin{array}{c}\text { Analysing } \\
\text { errors in an } \\
\text { abstract }\end{array}$ & 0 & 0.157 \\
\hline $\begin{array}{c}\text { Writing a } \\
\text { motivation } \\
\text { letter }\end{array}$ & 0.800 & 1 & $\begin{array}{c}\text { Arranging a } \\
\text { scrambled } \\
\text { motivation } \\
\text { letter / } \\
\text { abstract }\end{array}$ & 0.933 & 0.631 \\
\hline $\begin{array}{c}\text { Answering } \\
\text { tricky job } \\
\text { interview } \\
\text { questions }\end{array}$ & 0.866 & 0.894 & $\begin{array}{c}\text { Naming job } \\
\text { priorities }\end{array}$ & 0.733 & 0.421 \\
\hline
\end{tabular}

A number of similarities can be observed if completion of individual assignments is compared. Both cohorts share relatively high mean scores of homework participation, full participation in the first homework - "Creating a picture dictionary", and the lowest mean participation in the third extra task - "Analyzing errors in an abstract".

The predicted reasons for the presented outcomes are discussed below.

\section{4) Factors influencing students' participation}

We identified four factors which had affected the level of students' participation in learning activities on social media in the collected data.

\section{a) Reward}

High scores in homework and a moderate participation in extra tasks can be primarily assigned to "reward". At the start of each semester, we informed the students that they get 4 points for completing a homework assignment and 1 point for a completed extra task in the EAP Facebook group. The students could collect 25 points in total which corresponds with $25 \%$ in the overall assessment.

The sense of being rewarded and the fact that they could improve their final assessment significantly, motivated them to work on both homework and extra tasks. The participants communicated this also in the diaries:

Student 4a: "When I know that I can get something additional for my activities, it motivates me."

Student 10a: "I did every homework assignment, because 
I was driven by the chance to get some points and a better mark."

Student 13a: “[...] both the others' comments and extra points motivated me. Sometimes, I completed an extra task only to get another point."

Student 18a: "I was motivated mostly by the points."

Student 11b: "I would welcome even more tasks and points."

Student 17b: "I like extra tasks. A point can always come in handy. Hopefully, it will help me in the assessment."

b) Effort

We predict that students did not respond to the third extra task because it required higher effort for the same reward than the other ones.

From the four extra tasks that we analyzed, three required lower-order thinking skills, namely understanding and applying. Students were asked to express their opinions via comments or to put disarranged paragraphs / sentences in the correct order and send the correct solution via a private message. These simple tasks (from the aspects of needed mental effort and social media skills) achieved mean participation from 0.577 to 0.813 for the whole sample.

On the other hand, the remaining extra task (error analysis) involved analyzing (a higher-order thinking skill), and therefore required greater effort in the cognitive dimension than the previously described extra tasks. Participants analyzed abstracts written by other students and commented on structural, formal, or content errors. The mean score of participation in this activity was 0.078 .

c) Study environment

One student claimed in her diary that she did not participate in every Facebook assignment due to the way how the group's content was organized.

Student 12a: "Sometimes, I didn't even notice that there was a task to accomplish. Every time someone posted something in the group, it automatically popped up at the top of the page, and it was difficult to find the task when everybody was already posting their work. That's why I didn't complete every task."

\section{d) Workload}

Student diaries also provided limited evidence that participation in the Facebook activities was influenced by workload from other subjects.

Student 14a: "This week, we had tons of homework from other subjects. It was like Jesus, I still have to do Facebook homework. I didn't do it. I simply didn't have energy."

Student 16b: "The last two weeks have been stressful. There were other things to do, not only English. I didn't want to slack off in my core subjects, so I didn't complete the extra tasks."

\section{B. Preference}

Since Facebook groups are constructivist learning environments, collaboration is one of their integral features. But do the participants favor such activities, or do they prefer to work individually?

In order to determine students' preferences, we calculated mean participation in collaborative and non-collaborative assignments. The results are displayed below, in Table V.
TABLE V: MEAN SCORES OF STUDENTS' PARTICIPATION IN COLLABORATIVE AND NON-COLLABORATIVE FACEBOOK ASSIGNMENTS

\begin{tabular}{c|c|c}
\multirow{2}{*}{ Cohort } & \multicolumn{2}{|c}{ Participation $(\overline{\mathbf{x}})$} \\
\cline { 2 - 3 } & $\begin{array}{c}\text { Collaborative } \\
\text { assignments }\end{array}$ & $\begin{array}{c}\text { Non-collaborativ } \\
\text { e assignments }\end{array}$ \\
\hline $\mathbf{1}\left(\mathbf{N}^{\mathrm{a}}=\mathbf{1 5}\right)$ & 0.911 & 0.714 \\
\hline $\mathbf{2}\left(\mathbf{N}^{\mathrm{b}}=\mathbf{1 9}\right)$ & 0.982 & 0.654
\end{tabular}

The three activities that required collaboration (namely "Creating a picture dictionary", "Creating a database of facts about schooling”, and "Analyzing the structure of an abstract") scored statistically higher $(\overline{\mathrm{x}}=0.911 / 0.982)$ than the other seven activities in which participants worked on their own $(\overline{\mathrm{x}}=0.714 / 0.654)$.

The statistical data are further supported by diary entries:

Student 6b: "I like the tasks in which students can help each other."

Student 9b: "The pair homework in which students cooperated and analyzed an abstract was the most interesting one."

\section{Convenience}

Our diary data showed that convenience was threefold. First, completion of a Facebook assignment was convenient, because it was independent from time and/or location, as the participants commented.

Student 2a: "I can work on my way home and then do other things at home."

Student 14b: "I didn't do homework only at home. I could complete the activities everywhere and anytime."

Student 17b: "We can do homework literally in bed. We don't have to write anything on paper, submit anything in printed form, or look for homework in textbooks."

Student 20b: "It was the right way of doing homework, because the Internet is accessible nearly everywhere and to almost everyone."

Second, some participants viewed doing homework on Facebook as convenient due to their familiarity with this social media environment.

Student 5b: "It was a practical way of doing homework, because the activities could be completed directly on Facebook, and I didn't have to learn how to use some other system."

Student 13b: "I use Facebook daily, so it's easy to submit homework there."

Third and last, the participants praised time-effectivity of doing homework and extra tasks on Facebook.

Student 2a: "Doing homework on Facebook was a lot faster than doing it with pen and paper."

Student 9b: "Uploading homework was not time-consuming as in our literature Moodle course. It took me eight minutes to upload homework from Realism there, but only one minute to do it in our Facebook group."

However, students also complained that the activities on Facebook are time-consuming. We attribute this to their inability to separate the informal (private life) and the formal (education).

Student 13a: "Somebody posted something on my wall, so I looked at it. It took me almost half an hour until I started to do homework."

Student 14b: "Last time, I spent thirty minutes doing homework instead of ten, because people messaged me." 
Student 19b: "As I was doing homework, I saw that my favourite hockey team had lost a match. I wanted to know why, so I watched a video on my Facebook wall. I started at I a.m."

\section{DISCUSSION}

This paper inspected outcomes of regular homework and spontaneous, additional assignments within three categories, namely participation, preference, and convenience.

Similarly to reference [36], a relatively high overall mean participation in the ten Facebook assignments has been observed in both cohorts $(\bar{x}=7.7 / 7.5)$.

However, we did not only calculate overall participation, but we also looked at students' mean participation in homework assignments and extra tasks individually. The results indicate higher levels of students' participation in homework ( $\bar{x}=4.4 / 4.8$; max. 5) than in the extra tasks $(\bar{x}=3.3 / 2.6$; max. 5$)$.

Individuals' participation also showed that all students $(N=34)$ engaged in the first homework assignment ("Creating a picture dictionary"). When looking at students' engagement in homework from the perspective of individual cohorts, full participation was observed in "Creating a database of facts about schooling" (cohort 1), "Analyzing the structure of an abstract" (cohort 2), and "Writing a motivation letter" (cohort 2). The other homework assignments achieved lower mean scores, ranging from 0.733 to 0.947 .

In terms of the extra tasks, none of them was completed by all participants. The most successful ones were "Arranging $a$ scrambled motivation letter" (cohort 1) and "Summarizing reasons for enrolling in English classes" (cohort 2) with mean participation 0.933 for the former and 0.894 for the latter. The Facebook activity that almost all students ignored was "Analyzing errors in an abstract". In particular, only three students from cohort 2 participated in this extra task.

Our data also allowed us to identify four factors that promoted active participation in the Facebook assignments. Here, they are compared with theory.

Prior research linked students' participation in Facebook activities with interactivity [11], [12], audience [10], reading habits [10], non-static structure [4], and other academic duties [9], [12].

Our diary data replicated the last two factors which have a negative impact on participation. A student complained that her limited engagement was caused by her inability to locate the required instructions in the dynamic environment of the Facebook group. Two other students, on the other hand, felt overwhelmed by the amount of work in other courses, so they did not even try to participate.

The other two factors that influenced students' participation, namely reward and effort, have not been discussed in the literature review. The main positive driver of active involvement in the language learning activities conducted on Facebook seemed to be the opportunity of being rewarded with additional points that eventually contributed to overall assessment. Furthermore, we believe that not only the reward itself, but also the effort that was needed to get the reward influenced students' participation, since the extra tasks that required lower-order thinking skills achieved significantly higher scores of mean participation (from 0.577 to 0.813 ) than the one extra task that was based on the use of higher-order thinking skills $(\bar{x}=0.078)$.

Mean participation also indicated students' preference for constructivist learning, as collaborative tasks achieved higher scores $(\bar{x}=0.911 / 0.982)$ than individual tasks $(\bar{x}=0.714 / 0.654)$. This finding contradicts with the assumption that EFL learners lack confidence to learn within a community [38]. On the contrary, it supports the belief that collaboration belongs to the main pros of using Facebook groups as homework platforms [36], [37].

Apart from collaboration, students praise easy and convenient homework submission too [36], [37]. Our participants also valued these aspects of Facebook assignments. They viewed their completion as time / space independent, user-friendly, and time-saving. However, few students believed that doing homework on Facebook is time-consuming. Their diaries imply that they did not separate entertainment from learning, which supports the hypothesis that multi-tasking (i.e. non-educational use of Facebook during educational activities) negatively influences learning [35].

\section{CONCLUSION}

Extending foreign language exposure, including contact with the language via homework is beneficial for learning outcomes. The paper presents the author's experience with optional regular homework and irregular extra tasks completed by EAP students on Facebook. The question is, are Facebook groups suitable for delivering such content?

Based on the results of our case study, the answer is positive, but the following recommendations are worth considering when implementing Facebook groups as platforms for language learning activities outside the class:

1) Create a secret group to enforce the sense of safety and privacy and to lower the interference with personal life;

2) Provide enough input in the form of a variety of voluntary activities such as simple tasks that can be easily completed on the go or more complex collaborative assignments;

3) Reward your students adequately for their participation;

4) Take the dynamic organization of the group's content, students' effort, and their academic duties into consideration when designing the activities, as these factors seem to influence participation too;

5) Keep in mind that students can multi-task on Facebook (i.e. engage in personal matters when participating in educational tasks on this platform) which can delay or extend homework completion.

Our exploratory study has also further research implications, mainly in the participation dimension. Subsequent research shall measure the effects of reward, effort, study environment, and workload on participation in Facebook homework. It could also determine the importance of the factors identified.

\section{CONFLICT OF INTEREST}


The author declares no conflict of interest.

\section{AUTHOR CONTRIBUtions}

Juraj Datko conducted the research, analyzed the data, and wrote the paper.

\section{REFERENCES}

[1] J. Clement, Facebook: Number of Monthly Active Users Worldwide 2008-2020, Nov. 2020.

[2] A. M. Fewkes and M. McCabe, "Facebook: Learning tool or distraction?" Journal of Digital Learning in Teacher Education, vol. 28, no. 3, pp. 92-98, 2012.

[3] T. Anderson, "Distance learning - Social software's killer ap?" ODLAA, pp. 1-12, Jan. 2005.

[4] H. Meishar-Tal, G. Kurtz, and E. Pieterse, "Facebook groups as LMS A case study," The International Review of Research in Open and Distance Learning, vol. 13, no. 4, pp. 33-48, Sep. 2012.

[5] S. Manca and M. Ranieri, "Is it a tool suitable for learning? A critical review of the literature on Facebook as a technology-enhanced learning environment," Journal of Computer Assisted Learning, vol. 29, no. 6, pp. 487-504, Dec. 2013.

[6] T. Romano, "Defining fun and seeking flow in English language arts," English Journal, vol. 98, no. 6, pp. 30-37, July 2009.

[7] M. K. Kabilan, N. Ahmad, and M. J. Z. Abidin, "Facebook: An online environment for learning of English in institutions of higher education?" Internet and Higher Education, vol. 13, no. 4, pp. 179-187, 2010.

[8] M. N. Simpson, “ESL@Facebook: A teacher's diary on using Facebook," Teaching English with Technology, vol. 12, no. 3, pp. 36-48, 2012.

[9] L. Hsu, "Leveraging interactivities on social networking sites for EFL learning," International Journal of English Language Education, vol. 1 , no. 3, pp. 244-270, July 2013.

[10] N. A. Razak, M. Saeed, and Z. Ahmad, "Adopting social networking sites (SNSs) as interactive communities among English foreign language (EFL) learners in writing: Opportunities and challenges,' English Language Teaching, vol. 6, no. 11, pp. 187-198, Oct. 2013.

[11] Y-C. Sun, "Extensive writing in foreign-language classrooms: A blogging approach," Innovation in Education and Teaching International, vol. 47, no. 3, pp. 327-339, Aug. 2010.

[12] M. M. Yunus, H. Salehi, and C. Chenzi, "Integrating social networking tools into ESL writing classroom: Strengths and weaknesses," English Language Teaching, vol. 5, no. 8, pp. 42-48, July 2012.

[13] J. Datko, "Fostering self-directed EFL learning via Facebook group," International Masaryk Conference for Ph.D. Students and Young Researchers Proceedings, pp. 963-968, vol. 9, 2018

[14] J. D. Ophus and J. T. Abbitt, "Exploring the potential perceptions of social networking systems in university courses," MERLOT Journal of Online Learning and Teaching, vol. 5, no. 4, pp. 639-648, Dec. 2009.

[15] C. Irwin, L. Ball, B. Desbrow, and M. Leveritt, "Students' perceptions of using Facebook as an interactive learning resource at university," Australasian Journal of Educational Technology, vol. 28, no. 7, pp 1221-1232, Aug. 2012.

[16] B. S. Jong, Ch-H. Lai, Y-T Hsia, T-W. Lin, and Y-S Liao, "An exploration of the potential educational value of Facebook," Computers in Human Behavior, vol. 32, pp. 201-211, Mar. 2014.

[17] S. Al-Shehri, "Connectivism: A new pathway for theorizing and promoting mobile language learning," International Journal of Innovation and Leadership on the Teaching of Humanities, vol. 1, no. 2 , pp. 10-31, May 2011.

[18] C. McLoughlin and M. J. Lee, "Personalised and self regulated learning in the web 2.0 era: International exemplars of innovative pedagogy using social software," Australasian Journal of Educational Technology, vol. 26, no. 1, pp.1-27, Jan. 2010.

[19] H. T. Hung and S. C. Y. Yuen, "Educational use of social networking technology in higher education," Teaching in Higher Education, vol. 15 , no. 6 , pp. 703-714, Oct. 2010.

[20] J. Lave and E. Wenger, Situated Learning. Legitimate Peripheral Participation, Cambridge, U.K.: Cambridge University Press, 1991, ch. 4, pp. 89-118.

[21] B. Poellhuber, N. Roy, and T. Anderson, "Distance students' readiness for social media and collaboration," The International Review of Research in Open and Distance Learning, vol. 12, no. 6, pp. 102-125, Oct. 2011.
[22] A. M., Tervakari, K. Silius, T. Tebest, J. Marttila, M. Kailanto, and J. Huhtamaki, "Peer learning in social media enhanced learning environment," International Journal of Emerging Technologies in Learning, vol. 7, no. 3, pp. 35-42, 2012.

[23] S. D. Ryan, M. J. Magro, and J. H. Sharp, "Exploring educational and cultural adaptation through social networking sites," Journal of Information Technology Education: Innovations in Practice, vol. 10, pp. 1-16, 2011

[24] J. McCarthy, "Blended learning environments: Using social networking sites to enhance the first year experience," Australasian Journal of Educational Technology, vol. 26, no. 6, pp. 729-740, Oct. 2010.

[25] D. Schaffhauser, "Boundless opportunity," T.H.E.Journal, vol. 36, no. 9, pp. 13-18, Jan. 2009.

[26] J. Berg, L. Berquam, and K. Christoph, "Social networking technologies: A "poke" for campus services," EDUCAUSE Review, vol. 42, no. 2, pp. 32-44, 2007.

[27] J. Pasek, E. More, and E. Hargittai, "Facebook and academic performance: Reconciling a media sensation with data," First Monday, vol. 14, no. 5, pp. 1-15, May 2009.

[28] P. A. Kirschner and A. C. Karpinski, "Facebook and academic performance," Computers in Human Behavior, vol. 26, no. 6, pp 1237-1245, 2010.

[29] J. Paul, H. M. Baker, and J. Cochran, "Effect of online social networking on student academic performance," Computers in Human Behavior, vol. 28, no. 6, pp. 2117-2127, Oct. 2012

[30] P. Sendurur, E. Sendurur, and R. Yilmaz, "Examination of the social network sites usage patterns of preservice teachers," Computers in Human Behavior, vol. 51, pp. 188-194, Oct. 2015.

[31] E. Asante and E. M. Martey, "Impact of social media usage on academic performance of tertiary institution students: Evidence from Accra \& Tema metropolis, Ghana," Journal of Advance Research in Social Science and Humanities, vol. 1, no. 3, pp. 1-14, Mar. 2015.

[32] L. Leung, "A panel study on the effects of social media use and internet connectedness on academic performance and social support," International Journal of Cyber Behavior, Psychology and Learning, vol. 5, no. 1, pp. 1-16, 2015.

[33] E. V. Brubaker, "The relationship between FacebookTM activity and academic performance among African American students," PhD. Dissertation, Liberty University, Lynchburg, 2014.

[34] H. Huang, Social Media Generation in Urban China, Berlin, Germany: Springer, 2014, ch. 6, pp. 103-112.

[35] C. Marker, T. Gnambs, and M. Appel, "Active on Facebook and failing at school? Meta-analytic findings on the relationship between online social networking activities and academic achievement," Educational Psychology Review, vol. 30, pp. 651-677, Dec. 2017.

[36] V. Taecharungroj, "Homework on social media: Benefits and outcomes of Facebook as a pedagogic tool," International Journal of e-Education, e-Business, e-Management and e-Learning, vol. 3, no. 3, pp. 258-263, June 2013.

[37] O. Kitchakarn, "How students perceived social media as a learning tool in enhancing their language learning performance," The Turkish Online Journal of Educational Technology, vol. 15, no. 4, pp. 53-60, Oct. 2016.

[38] S. A. A. Kasuma, "Four characteristics of Facebook activities for English language learning: A study of Malaysian university students' needs and preferences," Advances in Language and Literary Studies, vol. 8, no. 3, pp. 155-171, June 2017.

[39] R-C. Shih, "Can web 2.0 technology assist college students in learning English writing? Integrating Facebook and peer assessment with blended learning," Australasian Journal of Educational Technology, vol. 27, no. 5, pp. 829-845, 2011.

[40] N. A. Bani-Hani, M. A. Al-Sobh, and A-R. H. Abu-Melhim, "Utilizing Facebook groups in teaching writing: Jordanian EFL students' perceptions and attitudes," International Journal of English Linguistics, vol. 4, no. 5, pp. 27-34, Oct. 2014

[41] H. Karal, M. Kokoc, and O. Cakir, "Impact of the educational use of Facebook group on the high school students' proper usage of language," Education and Information Technologies, vol. 22, pp. 677-695, Sep. 2015.

[42] S. M. Anwaruddin, "Learning English in the age of Facebook," Journal of Technology for ELT, vol. 2, no. 3, Sep. 2012.

[43] L. W. Anderson et al., A Taxonomy for Learning, Teaching, and Assessing, New York, USA: Longman, 2001, ch. 3, pp. 27-37.

Copyright (C) 2021 by the authors. This is an open access article distributed under the Creative Commons Attribution License which permits unrestricted 
use, distribution, and reproduction in any medium, provided the original work is properly cited (CC BY 4.0).

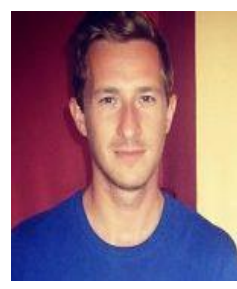

Mgr. Juraj Datko is a lecturer at constantine the Philosopher University in Nitra, Slovakia. He focuses on teaching English as a foreign language. He is an author of thirteen research studies and co-author of three books. His publications deal with pronunciation teaching and the use of media / social media in foreign language education. 